\title{
Peptide lineup against Gram-negative bacterial infection - first-in-class peptide inhibitor of H. pylori HtrA
}

Anna M Perna ${ }^{1 *}$, Thomas Schmidt ${ }^{2}$, Tim Fugmann $^{3}$, Nicole Tegtmeyer ${ }^{4}$, Steffen Backert ${ }^{4}$, Silja Wessler $^{2}$, G Schneider $^{1}$

From 9th German Conference on Chemoinformatics Fulda, Germany. 10-12 November 2013

More than $50 \%$ of the world population is infected with Helicobacter pylori (H. pylori) and the actual H. pylori treatments fail with increased regularity because of continuously rising antibiotic resistances. To meet this challenge, we focus on the development of a new antiinfective therapy against $H$. pylori by targeting a secreted enzyme, high temperature requirement A ( $\mathrm{HtrA})$. Release of the serine protease HtrA near the host's gastric epithelial cells leads to loss of cellular adhesion due to E- cadherin cleavage [1]. We investigated the substrate cleavage sites of HtrA in its natural substrate E-cadherin performing a label-free mass spectrometrybased proteomic analysis and identified preferred cleavage positions by Edman sequencing. Further, we developed the first HtrA peptide inhibitor by synthesizing cleavage site fragments and analogues. Surface plasmon resonance (SPR) was used to perform binding studies. In vitro substrate cleavage assays as well as cellular infection assays fully support the biophysical data.
doi:10.1186/1758-2946-6-S1-P46

Cite this article as: Perna et al.: Peptide lineup against Gram-negative bacterial infection - first-in-class peptide inhibitor of $H$. pylori HtrA. Journal of Cheminformatics 2014 6(Suppl 1):P46.

\section{Authors' details}

'Department of Chemistry and Applied Biosciences, Swiss Federal Institute of Technology (ETH), Zurich, 8093, Switzerland. ${ }^{2}$ Department of Molecular Biology, University of Salzburg, Salzburg, 5020, Austria. ${ }^{3}$ Philochem AG, Otelfingen, 8112, Switzerland. ${ }^{4}$ Department of Biology, University of Erlangen-Nuremberg, Erlangen, 91058, Germany.

Published: 11 March 2014

\section{Reference}

1. Hoy B, Löwer M, Weydig C, Carra G, Tegtmeyer N, Geppert T, Schröder P, Sewald N, Backert S, Schneider G, Wessler S: EMBO Rep 2010, 11:798-804.

'Department of Chemistry and Applied Biosciences, Swiss Federal Institute of Technology (ETH), Zurich, 8093, Switzerland

Full list of author information is available at the end of the article

\section{Publish with ChemistryCentral and every scientist can read your work free of charge \\ "Open access provides opportunities to our colleagues in other parts of the globe, by allowing anyone to view the content free of charge." \\ W. Jeffery Hurst, The Hershey Company. \\ - available free of charge to the entire scientific community \\ - peer reviewed and published immediately upon acceptance \\ - cited in PubMed and archived on PubMed Central \\ - yours - you keep the copyright \\ Submit your manuscript here: \\ http://www.chemistrycentral.com/manuscript/

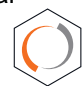 \\ ChemistryCentral}

